\title{
IMPLIED CONSENT TO SUMMARY JURISDICTION IN BANKRUPTCY: THE FORGOTTEN RIGHT TO JURY TRIAL
}

In sections $2^{1}$ and $23^{2}$ of the Bankruptcy Act, Congress has established a jurisdictional scheme which distinguishes between controversies "at law and equity" and "proceedings under this act." 3 The district courts, denominated courts of bankruptcy, have jurisdiction over all proceedings arising under the Bankruptcy Act. ${ }^{4}$ Controversies at law and equity between trustees and adverse claimants, on the other hand, may ordinarily be brought only where the bankrupt might have brought suit if proceedings in bankruptcy had not been instituted. Exceptions are provided where the defendant consents or where the issue in controversy falls within sections 60,67 or 70 of the act. ${ }^{5}$

In addition to establishing this jurisdictional scheme Congress has also provided for both plenary and summary proceedings. ${ }^{6}$ A summary proceeding differs from a plenary proceeding in the following respects :

The former is based upon petition and proceeds without formal pleadings; the latter proceeds upon formal pleadings. In the former, the necessary parties are cited in by order to show cause; in the latter, formal summons brings in the parties other than the plaintiff. In the former, short time notice of hearing is fixed by the court; in the latter, time for pleading and hearing is fixed by statute or rule of court. In the former, the hearing is quite

1 Bankruptcy Act $\S 2(a), 52$ Stat. 842 (1938), 11 U.S.C. $\S 11$ (1964), provides: The courts of the United States hereinbefore defined as courts of bankruptcy are hereby created courts of bankruptcy and are hereby invested, within their respective territorial limits as now established or as they may be hereafter changed, with such jurisdiction at law and in equity as will enable them to exercise original jurisdiction in proceedings under this Act ....

2 Bankruptcy Act §23, 52 Stat. 854 (1938), 11 U.S.C. $\$ 46$ (1964), provides :

a. The United States district courts shall have jurisdiction of all controversies at law and in equity, as distinguished from proceedings under this Act, between receivers and trustees as such and adverse claimants, concerning the property acquired or claimed by the receivers or trustees, in the same manner and to the same extent as though such proceedings had not been instituted and such controversies had been between the bankrupts and such adverse claimants.

b. Suits by the receiver and the trustee shall be brought or prosecuted only in the courts where the bankrupt might have brought or prosecuted them if proceedings under this Act had not been instituted, unless by consent of the defendant except as provided in sections 60, 67, and 70 of this Act.

3 Compare Bankruptcy Act $\$ 23(2), 52$ Stat. 854 (1938), 11 U.S.C. $\$ 46(a)$ (1964), with Bankruptcy Act $\$ 2$ (a), 52 Stat. 842 (1938), 11 U.S.C. $\$ 11$ (1964).

4 Bankruptcy Act $\S 2(a), 52$ Stat. 842 (1938), 11 U.S.C. $\$ 11(a)$ (1964). For the complete text of this section see note 1 supra.

5 Bankruptcy Act $\S 23,52$ Stat. 854 (1938), 11 U.S.C. $\$ 46$ (1964). For the complete text of this section see note 3 supra.

6 See 2 Collier, Bankruptcy If 23.02[1] (14th ed. 1964); MacLachlan, BankRUPTCY \$ 193 (1956). 
generally upon affidavits; in the latter, examination of witnesses is the usual method. In the former, the hearing is sometimes ex parte; in the latter, a full hearing is had.?

In addition, there is a right to jury trial in plenary proceedings in accord with usual common law rules, while no such right is afforded in summary proceedings. ${ }^{8}$ The type of proceeding applicable in any given adjudication usually depends upon whether the trustee or the claimant has actual or constructive possession of the property in question. ${ }^{9}$

When a creditor files a claim, the bankruptcy court will ordinarily have jurisdiction to adjudicate the merits of his claim in a summary manner, since it has possession of the bankrupt's property. However, a problem arises if the trustee files a counterclaim against the creditor in the same proceeding. In this situation, the bankruptcy court ordinarily does not have actual or constructive possession of the property which the trustee is claiming. Thus, if the trustee had pursued his claim as an original action rather than as a counterclaim, he would have had to sue where the bankrupt could have sued had there been no bankruptcy and the defendant would have been entitled to a plenary proceeding. Creditors, it should be noted, prefer this result and would like to have the trustee's counterclaim similarly adjudicated by a plenary proceeding and a jury trial on the issues. ${ }^{10}$ The majority of the circuit courts, however, have held that the trustee's counterclaim may be adjudicated in a summary proceeding if it is related to the creditor's original claim.11 Their reasoning has been that by filing his claim the creditor has impliedly consented to the bankruptcy court's summary jurisdiction, and that a subsequent objection to summary proceedings on the counterclaim will be ineffective.

This Comment will examine the consent doctrine as it has been established in the federal courts, focusing upon the extent to which an implied consent rationale should determine whether a proceeding is summary or plenary. An attempt will be made to demonstrate the severability of

7 Central Republic Bank \& Trust Co. v. Caldwell, 58 F.2d 721, 731-32 (8th Cir. 1932); see CollIER, op. cit, supra note $6, \pi 23.02[2]$.

8 MacLachlan, op. cit. supra note $6, \S 193$.

9 In proceedings arising under the Bankruptcy Act, the district courts, sitting as courts of bankruptcy, have jurisdiction to adjudicate certain enumerated controversies by way of summary proceedings. Bankruptcy Act $\$ 2(2)(1)-(22), 52$ Stat 842 (1938), as amended, 11 U.S.C. \&11(a) (1)-(21) (1964).

10 See, e.g., Inter-State Nat'l Bank v. Luther, 221 F.2d 382 (10th Cir. 1955), cert. dismissed per stipulation, 350 U.S. 944 (1956).

11 Katchen v. Landy, 336 F.2d 535 (10th Cir. 1964), cert. granted, 380 U.S. 971 (1965); Powell v. Maher, 307 F.2d 397 (D.C. Cir.) (per curiam), cert. denied, 371 U.S. 910 (1962); Peters v. Lines, 275 F.2d 919 (9th Cir. 1960) ; Continental Cas. Co. v. White, 269 F.2d 213 (4th Cir. 1959); In re Solar Mfg. Corp., 200 F.2d 327 (3d Cir. 1952), cert. dertied, 345 U.S. 940 (1953); Florance v. Kresge, 93 F.2d 784 (4th Cir. 1938) ; see In the Matter of Majestic Radio \& Television Corp., 227 F.2d 152 (7th Cir. 1955) (dictum), cert. denied, 350 U.S. 995 (1956); Inter-State Nat'1 Bank v. Luther, 221 F.2d 382 (10th Cir. 1955), cert. dismissed per stipulation, 350 U.S. 944 (1956) ; cf. Chase Nat'l Bank v. Lyford, 147 F.2d 273 (2d Cir. 1945). Contra, B. F. Avery \& Sons v. Davis, 192 F.2d 255 (5th Cir. 1951), cert. denied, 342 U.S. 945 (1952). 
the concept of consent to jurisdiction from that of consent to a particular mode of proceeding. The discussion will be concerned with the counterclaim situation, since the present formulation of the consent doctrine has its greatest effect there by depriving the claimant of a jury trial on the issues presented by the counterclaim.

\section{Constructing a Doctrine}

Alexander v. Hillman, 12 a 1935 Supreme Court decision, provided the foundation on which the circuit courts erected their consent by filing doctrine. The Hillman case was a receivership proceeding in which certain officers and directors of the corporation in receivership filed claims with the special master for unpaid salaries and other expenses. The receiver subsequently filed an ancillary bill of complaint against these claimants, alleging that they had mismanaged the corporation funds and had obtained the bankrupt's property fraudulently. In affirming the lower court decision, the Fourth Circuit Court of Appeals ruled that the district court lacked jurisdiction to award affirmative relief on the counterclaim filed by the receiver. ${ }^{13}$ Since the claimant was not in a court of his own choosing, ${ }^{14}$ the court reasoned, no consent to be sued by way of counterclaim could be implied from his filing of a claim. Furthermore, even though the creditor waived any right to jury trial on his claim by filing it in a court of equity, he did not thereby waive that right for a counterclaim involving an action at law. ${ }^{15}$ Although the Supreme Court reversed, it did not pass upon the jury trial issue, since it decided the case on the following basis:

Causes of action arising from transgressions of officers and directors of corporations such as those on which the receivers rest their counterclaims are cognizable in equity for the reason that the receivers have no adequate remedy at law and also because respondents, as it is alleged, fraudulently obtained defendant's property and therefore cannot in equity and good conscience retain it. ${ }^{16}$

The Constitution protects the right to jury trial only insofar as it existed at common law. ${ }^{17}$ Since the right had never attached to equitable causes of action, the jury trial issue disappeared from Hillman when the counterclaim was classified as an equitable one. From the facts of the Supreme Court opinion, the strongest holding that can be gleaned from

12296 U.S. 222 (1935).

13 Alexander v. Hillman, 75 F.2d 451 (4th Cir. 1935).

14 Id. at 455.

15 Ibid.

16 Alexander v. Hillman, 296 U.S. 222, 240 (1935). (Emphasis added.)

17 U.S. CoNST. amend. VII provides: "In Suits at common law, where the value in controversy shall exceed twenty dollars, the right of trial by jury shall be preserved, and no fact tried by a jury, shall be otherwise reexamined in any Court of the United States, than according to the rules of the common law." 
Hillman is that when a claim is filed in an equity receivership, the equity court can adjudicate counterclaims which were cognizable in equity. ${ }^{18}$ The circuit courts, however, did not so limit their holdings. Three years after Hillman, the Fourth Circuit held that when the trustee's counterclaim arises out of the same transaction as the creditor's claim, the bankruptcy court can grant affirmative relief against the creditor in the summary proceeding. ${ }^{19}$ The court did not attempt to classify the counterclaim as legal or equitable, nor did it discuss the jury trial issue. It chose instead simply to rest its decision on Hillman, without any discussion of the factual differences between the two cases. This version of the consent doctrine then spread through most of the circuits in a pyramid process, each new court citing Hillman and the other circuit court decisions purporting to follow it. At one point, the Tenth Circuit even extended the scope of summary jurisdiction to unrelated counterclaims. ${ }^{20}$ The right to jury trial on legal counterclaims went unmentioned in most of the decisions, and only the dissenting opinions in Inter-State Nat'l Bank v. Luther ${ }^{21}$ and Katchen v. Landy ${ }^{22}$ gave consideration to this issue.

In devising their consent doctrine, the circuit courts have failed to separate three related concepts. To begin with, the initial filing of a creditor's claim has been taken to imply not only consent to the court's jurisdiction, but also consent to summary proceedings. The courts have not only confused these two concepts, but have also neglected to give separate consideration to the jury trial question. In implying consent to jurisdiction, no distinction has been drawn between the consent needed to give a court power to adjudicate a controversy and the consent necessary to constitute a claimant's waiver of jury trial. The latter has been viewed as an inevitable consequence of the former. The courts' implication of the waiver of jury trial from consent to jurisdiction is the most difficult aspect of their thinking to rationalize and will be dealt with at length.

\section{Consent to Jurisdiction Equated to Consent to Summary Proceedings}

At first glance, the relevance of the courts' failure to distinguish consent to jurisdiction from consent to summary proceedings may be questioned. Other than the absence of jury trial there is little practical difference between plenary and summary proceedings. ${ }^{23}$ However, if it can be

18 For a similar analysis of the Supreme Court opinion see In re Nathan, 98 F. Supp. 686 (S.D. Cal. 1951).

19 Florance v. Kresge, 93 F.2d 784 (4th Cir. 1938).

20 Inter-State Nat'l Bank v. Iuther, 221 F.2d 382 (10th Cir. 1955), cert. dismissed per stipulation, 350 U.S. 944 (1956). In a recent case, however, it has retreated somewhat from that position. Katchen v. Landy, 336 F.2d 535 (10th Cir. 1964), cert. granted, 380 U.S. 971 (1965).

21221 F.2d 382 (10th Cir. 1955), cert. dismissed per stipulation, 350 U.S. 944 (1956).

22336 F.2d 535 (10th Cir. 1964), cert. granted, 380 U.S. 971 (1965).

23 See text accompanying note 7 supra. See generally MacLachlan, op. cit. supra note $6, \S 193$. 
shown that a creditor's filing of a claim should not be taken as implying consent even to the less important aspects of summary proceedings, it would follow logically that it should not be considered as a waiver of the seventh amendment right to jury trial. It is in this framework that the consent to summary proceedings issue assumes its real significance.

The argument most often advanced for permitting the adjudication of related counterclaims in summary proceedings is that such a course will help achieve speed and economy in bankruptcy litigation. ${ }^{24}$ The Federal Rules of Civil Procedure are often cited in support of this approach, since one of their basic purposes is the resolution of as many issues as possible in a single proceeding. The courts have also argued that since the trustee can have a summary adjudication of the issues upon which his counterclaim depends by raising these issues in answer to the claim, there is no reason for compelling him to institute a plenary action to obtain affirmative relief, since the issues adjudicated as defenses would be res judicata in a plenary suit. 25

Although settling all issues in one adjudication is both a desirable goal and one of the directives of the Federal Rules, this policy should not be applied in the bankruptcy context, since Congress has explicitly provided for different types of proceedings. In other words, it seems difficult to base decisions on an economy of litigation rationale when the governing statute requires that certain issues be adjudicated in a summary manner while others be resolved in plenary proceedings. ${ }^{26}$

The res judicata-more precisely, collateral estoppel-rationale also seems questionable. A threshold problem is whether the courts have been correct in holding that the issues adjudicated as defenses in a summary proceeding would be res judicata in a plenary suit. ${ }^{27}$ Where a court has limited subject matter jurisdiction, the collateral effect of its resolution of certain issues is also limited. Thus, if a court incidentally decides an issue which it would not have had jurisdiction to decide in a direct action, its decisions will only be conclusive for purposes of that particular case. ${ }^{28}$ They "zwill not be conclusive between the parties in a later suit brought .. . for the purpose of determining the matter directly in a court which

24 See, e.g., Peters v. Lines, 275 F.2d 919 (9th Cir. 1960).

25 E.g., In re Solar Mfg. Corp., 200 F.2d 327 (3d Cir. 1952), cert. denied sub nom., Marine Midland Trust Co. v. McGirl, 345 U.S. 940 (1953).

26 See Taubel-Scott-Kitzmiller Co. v. Fox, 264 U.S. 426, 433-34 (1924) : "[I]n no case where it lacked possession, could the bankruptcy court, under the law as originally enacted, nor can it now (without consent) adjudicate in a summary proceeding the validity of a substantial adverse claim." Id. at 433.

27 The courts have not questioned the applicability of the res judicata rationale, but merely have assumed that it applied in the bankruptcy context. See, e.g., In re Solar Mfg. Corp., 200 F.2d 327 ( $3 \mathrm{~d}$ Cir. 1952), cert. denied sub nom., Marine Midland Trust Co. v. McGirl, 345 U.S. 940 (1953); Schwartz v. Levine \& Malin, Inc., 111 F.2d 81 (2d Cir. 1940).

28 Restatement, JudgMents $\$ 71$ (1942). 
has jurisdiction to determine it directly." 29 The situation in which a trustee defends against a creditor's claim by alleging that the creditor had received a voidable preference may be used to show how this concept applies in the bankruptcy context. If the trustee had sued directly to recover the preference, the bankruptcy court normally would not have had summary jurisdiction to adjudicate the issue..$^{30}$ Since the trustee raised the issue only as a defense to the creditor's claim, however, the bankruptcy court would have summary jurisdiction to adjudicate its merits, for such a determination would be necessary to decide the validity of the creditor's claim, which admittedly is within its jurisdiction. Under the rule stated above, however, such a decision of the bankruptcy court would not be conclusive in a later action initiated by the trustee in a court having direct jurisdiction to determine the preference issue. Thus, the circuit courts' rationale for allowing the trustee to recover an affirmative judgment in the summary proceeding may not be required by the collateral estoppel doctrine.

Even if collateral estoppel were technically applicable in the bankruptcy context, it is still possible to question whether the doctrine should be applied. As one commentator has stated:

Res judicata, or more properly, collateral estoppel, is not an absolute imperative of the law. Res judicata represents a policy which, like other doctrines of the law, must be weighed and balanced when in conflict with competing policies. ${ }^{31}$

A close analysis of the Bankruptcy Act reveals that Congress has clearly articulated a competing policy by its careful distinction between summary and plenary proceedings. Since Congress, in establishing a complete system for bankruptcy administration, "deliberately struck a balance between summary and plenary proceedings [such] . . . balance ought not be lightly disregarded simply because a court might (perhaps rightly) believe the policy unwise." 32

While there has been little criticism of the rationales employed by the circuit courts, it is noteworthy that even Professor Moore, while supporting the collateral estoppel theory and favoring the summary adjudication of counterclaims, still is unwilling to have this procedure employed in every case. He states that:

29 Id., comment a. See Developments in the Law-Res Judicata, 65 HARv. I. REv. 818, 849 (1952) : "If the court of limited jurisdiction involved is a small claims court, its judgment obviously will not be given collateral effect because its purpose of giving 'quick justice' on the immediate issue requires it to hold only summary proceedings."

30 This hypothetical assumes that the trustee does not have actual or constructive possession of the property he is seeking to recover. The bankruptcy court thus would not have summary jurisdiction.

31 Ferguson, The Consensual Basis of Subject-Matter Jurisdiction in Matters of Bankruptcy: Fact and Fiction, 14 RuTGERS L. REv. 491, 515 (1960).

32 Ibid. 
When the objections to summary jurisdiction [on a counterclaim] in a particular case are sufficiently impelling, the bankruptcy court, as a court of equity and in the exercise of a sound discretion, should stay its hand and remit the trustee to a plenary suit. ${ }^{33}$

Though this reservation is hardly an indictment of the circuit court doctrine, it does demonstrate that the congressional distinction between plenary and summary proceedings should not go completely unnoticed in an effort to achieve more efficient bankruptcy administration.

The "consent by filing" doctrine is further weakened by an examination of the Bankruptcy Act itself. Section 23(a) of the act states that if a trustee claims property held by an adverse claimant, the federal court will have jurisdiction "in the same manner and to the same extent as though such [bankruptcy] proceedings had not been instituted and such controversies had been between the bankrupts and such adverse claimants." 34 This section is concerned solely with the power of the court to adjudicate a controversy. It does not speak to the nature of the proceedings to be employed once jurisdiction is obtained. Section $23(\mathrm{~b})$ of the act similarly gives no indication that summary proceedings will be held in the federal court, even if that court acquires jurisdiction by consent. That section ${ }^{35}$ states only that the trustee can bring a suit in a court where the bankrupt could not have brought it if the defendant consents to the jurisdiction. Some courts have clearly recognized the separability of consent to the power of a particular court to adjudicate a controversy from consent to a particular mode of proceeding. ${ }^{3 \mathrm{C}}$ One court has stated that "the consent mentioned in 23(b) means consent to the tribunal in which the controversy is to be carried on, and not to the mode of procedure ."37 There is thus no reason implicit in section 23(b) why a creditor can not recognize the power of the court to hear the counterclaim without losing his right to have it heard in a plenary manner. The concept of a separability of consent to jurisdiction from consent to summary proceedings has been recognized in another court's statement that "the objection to summary procedure does not go to the basic jurisdiction of the court but to its authority to proceed in a summary way." 38

The separability of the jurisdictional issue from the nature of the proceeding issue has been alluded to by the Supreme Court in MacDonald v. Plymouth County Trust $\mathrm{C}_{0 .}{ }^{39}$ In that case the trustee filed a petition

33 Moore, Res Judicata and Collateral Estoppel in Bankruptcy, 68 YALE L.J. 1, 38 (1958).

34 For the complete text of this section of the Bankruptcy Act, see note 2 supra. 35 Ibid.

${ }^{36}$ See In re Prima Co., 98 F.2d 952 (7th Cir.), cert. denied, 305 U.S. 658 (1938). 37 Sinsheimer v. Simonson, 107 Fed. 898, 906 (6th Cir. 1901), aff'd sub nom., Louisville Trust Co. v. Comingor, 184 U.S. 18 (1902).

38 First Nat'l Bank v. Fox, 111 F.2d 810, 813 (6th Cir. 1940).

39286 U.S. 263 (1932). 
with the referee to set aside preferences alleged to be voidable within the meaning of section $60(\mathrm{~b})$. The respondent agreed in open court to let the trial of the issues proceed before the referee, and the only question before the court was whether the referee had jurisdiction to determine the issue in a summary proceeding after the parties had consented. The Court concluded that a summary proceeding could be held, since the right to a plenary proceeding could be waived and was so waived by the claimant's consent in open court. However, the court went on to state that:

Where a suit by the trustee is plenary in character . . . both parties to it are entitled to claim the benefits of the procedure in a plenary suit, not available in the summary method of procedure . . . A denial of those benefits would be in effect a denial of the right to a plenary suit, to which both parties are entitled ....40

Thus neither the Bankruptcy Act nor the cases seem to afford the circuit courts a basis for implying consent to summary proceedings when a creditor files a claim.

In constructing the "consent by filing" doctrine, the circuit courts have given no weight to the fact that the creditor is forced to come to the bankruptcy court with its summary proceedings to present his original claim. The courts have simply reasoned that since a person beginning litigation ordinarily must face counterclaims made by the defendant, all claimants in bankruptcy should come to court prepared to adjudicate everything related to their claim. This approach is unpersuasive since it does not allow for the different type of proceeding which the claimant must enter in bankruptcy litigation to receive his share of the bankrupt's assets. Its effect has been to deprive a creditor who wishes to file a claim of the opportunity to appear specially. If the creditor makes a claim, he is considered to have made a general appearance, even though he may have no way of telling whether a counterclaim will be brought against him. This result is not in any way irrational, but it is difficult to understand why this particular class of litigants should not be allowed to make special appearances. Indeed, since the bankruptcy proceeding is an unusual one, and since Congress has carefully distinguished between summary and plenary proceedings, the special appearance technique would seem particularly appropriate in the bankruptcy field. The concept of quasi in rem jurisdiction demonstrates the acceptability of limited appearances in our system, and also establishes a framework for handling atypical situations which could guide the bankruptcy courts.

A court having quasi in rem jurisdiction cannot give judgment for more than the value of the property attached; ${ }^{41}$ in some states this rule

$40 \mathrm{Id}$. at $266-67$.

41 See Pennoyer v. Neff, 95 U.S. 714 (1877). 
applies even when the defendant comes to court. ${ }^{42}$ Such a procedure allows the defendant to litigate the merits without making a general appearance. The defendant in the quasi in rem suit occupies a position analogous to that of the claimant in a bankruptcy proceeding, for if the defendant does not appear, a default judgment may be rendered against him, ${ }^{43}$ while if the creditor fails to file his claim, he has no alternative way of collecting. ${ }^{44}$ Another conceptual similarity between quasi in rem jurisdiction and limited appearance in bankruptcy is that the jurisdiction in both is based on the court's actual or constructive possession of certain property. ${ }^{45}$ Although the analogy is by no means perfect, it does demonstrate that our system is not antagonistic to the concept of permitting a litigant to enter a particular forum free from an implication of consent to the tribunal's jurisdiction for all purposes.

In a 1932 decision, the Supreme Court indicated that a limited appearance is available in bankruptcy. The claimant in Daniel v. Guaranty Trust $\mathrm{Co}^{46}$ petitioned for reclamation of bonds held by the trustee. The trustee defended on this issue and also alleged that the claimant held money which belonged to the bankrupt. The referee ordered the trustee to give the bonds to the claimant and ordered the claimant to turn over the money to the trustee. On these facts, the Supreme Court held that the claimant did not enter a general appearance by filing its petition for reclamation and that it did not submit itself to summary proceedings on unrelated counterclaims. ${ }^{47}$ The Court added that the demand for speedy administration of bankrupt estates is not enough to justify such a radical departure from the ordinary procedure. ${ }^{48}$ Since it does not reach the ques-

42 See, e.g., Salmon Falls Mfg. Co. v. Midland Tire \& Rubber Co., 285 Fed. 214 (6th Cir. 1922); Cheshire Nat'l Bank v. Jaynes, 224 Mass. 14, 112 N.E. 500 (1916).

For a contrary result see United States v. Balanovski, 236 F.2d 298 (2d Cir. 1956), cert. denied, 352 U.S. 968 (1957), in which the court held that the defendant's appearance to defend on the merits gave the court power to render a judgment in personam. One line of reasoning employed by the court to reach its decision was that the "parties cannot complain of inconvenience, since they have come into the jurisdiction." 236 F.2d at 302 . However, as stated by one commentator, "this argument overlooks the fact that the defendant's participation is his only means of protecting his property and bears no relation to the convenience of the forum." Developments in the Laze-State-Court Jurisdiction, 73 HARV. L. REV. 909, 953 (1960). Another rationale used by the court was that a rule against personal jurisdiction would only produce further litigation whose merits would be determined by the doctrine of collateral estoppel. This collateral estoppel argument, however, may not be applicable in the bankruptcy context. See text accompanying notes 27-32 supra. Thus, those courts which prohibit limited appearances in quasi in rem actions hardly seem to provide any basis for denying limited appearances in bankruptcy proceedings. 43 Note, 97 U. PA. L. Rev. 403 (1949).

44 Bankruptcy Act $\$ 57(\mathrm{n}), 52$ Stat. 867 (1938), 11 U.S.C. $\S 93(\mathrm{~m})$ (1964). 455 Moore, Federal Practice \I 38.30[3] (2d ed. 1951).

46285 U.S. 154 (1932).

47 The risk incidental to a general appearance and consent to adjudication of claims of all kinds might easily deter where the right to recover is clear. Moreover, the choice would not be between tribunals merely, but between the ordinary processes in a plenary suit and a summary hearing.

Id. at 162 .

48 Ibid. 
tion of related counterclaims, Daniel does not settle the present problem. It does, however, erect a limit to the court's power to imply consent ${ }^{49}$ and is persuasive authority for requiring a court to articulate carefully its reasons for making such an implication in the related counterclaim situation. Furthermore, reasoning from the Daniel opinion, it would appear that the creditor should be protected from litigating even related counterclaims summarily. The only reason the Court allowed a special appearance in Daniel was that the trustee would have had to employ plenary proceedings if the creditor had not filed its claim. This is true, of course, whether the counterclaim is related or unrelated to the creditor's original claim.

\section{The Implication of Waiver of Jury Trial}

There is no doubt that the procedure currently employed by the courts is a quite expeditious method for handling bankruptcy problems. Were it not for one important difference between summary and plenary proceedings, the present judicial policy would probably be the most advisable, even in face of the objections that have been raised above. That difference, of course, is the right to jury trial in the plenary proceeding. ${ }^{50}$ The seventh amendment provides that "in suits at common law . . . the right of trial by jury shall be preserved. . . ." The Supreme Court has interpreted "common law" to include

not merely suits, which the common law recognized among its old and settled proceedings, but suits in which legal rights were to be ascertained and determined, in contradistinction to those where equitable rights alone were recognized . . . . In a just sense, the amendment then may well be construed to embrace all suits, which are not of equity and admiralty jurisdiction, whatever may be the peculiar form which they may assume to settle legal rights. ${ }^{51}$

The implication of waiver of this constitutional right must rest upon more substantial grounds than the desire to have more efficient bankruptcy administration. The circuit courts, however, have refused to accept this conclusion, cavalierly assuming that a claimant waives his right to jury trial on a legal counterclaim merely by filing his original claim. The assertion of one court is typical:

49 Compare Daniel v. Guaranty Trust Co., 285 U.S. 154 (1932), with Inter-State Nat'l Bank v. Luther, 221 F.2d 382 (10th Cir. 1955), cert. dismissed per stipulation, 350 U.S. 944 (1956).

50 See text accompanying notes 7-8 supra.

51 Parsons v. Bedford, 28 U.S. (3 Peters) 433, 447 (1830) (Story, J.); see Geneux v. Texas \& Pac. Ry., 98 F. Supp. 405, 409 (W.D. La. 1951) and cases cited therein for the present acceptability of this interpretation. 
To the contention that the Bank was denied the right to a jury trial, it need only be said that if, as we have held, the Bank impliedly consented to the summary jurisdiction of the court, it thereby pro tanto waived its right to a jury trial on the issues involved in the claim and counterclaim . . . .52

Closer analysis, however, suggests that two different types or degrees of consent are necessary to permit a court to find both jurisdiction and waiver of jury trial.

In implying waiver of jury trial the courts have relied heavily upon the equitable nature of the bankruptcy proceedings and the power of a court of equity to require the claimant to do equity before receiving equity.53 Employing this latter concept, the courts have demanded that the creditor be willing to adjudicate all matters related to his claim in a summary manner. This approach overlooks the fact that our system has always recognized a distinction between legal and equitable counterclaims, whether or not the original claim was equitable in nature. ${ }^{54}$

Outside the bankruptcy field it has never been held that a plaintiff waives his right to jury trial on legal counterclaims by instituting an equitable action..$^{55}$ It is true that under the premerger practice, the defendant in an equitable suit who asserted a legal counterclaim arising out of the plaintiff's original equitable claim ${ }^{56}$ waived his right to jury trial on the counterclaim. ${ }^{57}$ At the same time, the plaintiff's right to a jury trial on the legal counterclaim was still recognized. ${ }^{58}$ After the merger of law and equity, certain changes were effected. It was thought unfair that a defendant should lose his right to jury trial when filing a legal counterclaim related to the equitable claim, since the Federal Rules of Civil Procedure compelled him to file the counterclaim. ${ }^{59}$ Although the courts agreed that the defendant had a right to jury trial on the legal counterclaim, problems still remained. The basic question the courts could not resolve was the time at which the right to jury trial attached. Some courts held that the equitable claim should be tried first and that

52 Inter-State Nat'l Bank v. Luther, 221 F.2d 382, 390 (10th Cir. 1955), cert. dismissed per stipulation, 350 U.S. 944 (1956).

53 See, e.g., id. at 389; Chase Nat'l Bank v. Lyford, 147 F.2d 273 (2d Cir. 1945).

54 See American Mills Co. v. American Sur. Co., 260 U.S. 360 (1922) ; Clifton v. Tomb, 21 F.2d 893 (4th Cir. 1927).

55 See ibid. See generally 5 Moore, Federal Practice $\$ 38.14$ (2d ed. 1951); McCord, Right to Jury Trial in the Federal Courts, 45 IowA L. REv. 726 (1960).

56 The defendant's right to raise a legal counterclaim in such circumstances is enunciated in United States v. National City Bank, 83 F.2d 236 (2d Cir.), cert. denied, 299 U.S. 563 (1936).

57 See, e.g., American Mills Co. v. American Sur. Co., 260 U.S. 360, 366 (1922) ; Horowitz v. New York Life Ins. Co., 80 F.2d 295, 302 (9th Cir. 1935); Clifton v. Tomb, 21 F.2d 893, 898 (4th Cir. 1927).

58 See Clifton v. Tomb, supra note 57; National Elec. Prods. Corp. v. Circle Flexible Conduit Co., 57 F.2d 219 (E.D.N.Y. 1931) ; McCord, supra note 55.

59 See Note, The Right to Jury Trial Under Merged Procedures, 65 Harv. L. REv. 453 (1952). 
only issues not necessarily determined by the court in passing on the plaintiff's claim should later be submitted to the jury. ${ }^{60}$ Other courts searched for the "basic issue" in the case and decided whether a right to jury trial existed by determining whether that issue was legal or equitable. $^{61}$ Since the determination of either cause constituted collateral estoppel on common questions of fact in the other cause of action, a decision that the equitable cause be litigated first was for practical purposes a denial of the right to jury trial. ${ }^{62}$

In 1959, the Supreme Court in Beacon Theatres, Inc. v. Westover ${ }^{63}$ rendered a decision which greatly limited judicial power to curtail the right to jury trial. In that case, Fox West Coast Theatres sought a declaratory judgment that its activities were not in violation of the antitrust laws; it also sought an injunction to prevent Beacon Theatres from instituting antitrust actions. Beacon counterclaimed and asked for treble damages; it also asked for a jury trial. The district court held that the issues raised by the complaint for declarative relief were essentially equitable and it directed that these issues be tried by a court before jury determination of the counterclaim. The Supreme Court reversed, holding that Beacon Theatres had a right to jury trial on its legal claim for treble damages. The Court stated:

The justification for equity's deciding legal issues once it obtains jurisdiction, and refusing to dismiss a case, merely because subsequently a legal remedy becomes available, must be re-evaluated in the light of the liberal joinder provisions of the Federal Rules which allow legal and equitable causes to be brought and resolved in one civil action. ${ }^{04}$

On similar facts, the Supreme Court held recently in Dairy Queen v. Wood ${ }^{65}$ that unless there are unusual circumstances in a case involving both legal and equitable issues, a right to jury trial on the legal issues can not be lost through a prior determination of the equitable claims. It was no longer to matter that the equitable cause outweighed the legal cause and was the basic issue of the case; as long as any legal cause was involved the jury trial rights it created were controlling. ${ }^{66}$ These two cases clearly establish that the party who files the legal counterclaim must be given a jury trial on the legal issues.

60 See, e.g., Bendix Aviation Corp. v. Glass, 81 F. Supp. 645 (E.D. Pa. 1948).

61 See, e.g., General Motors Corp. v. California Research Corp., 9 F.R.D. 565

(D. Del. 1949).

62 See Leimer v. Woods, 196 F.2d 828 (8th Cir. 1952).

e3 359 U.S. 500 (1959).

64 Id. at 509.

65369 U.S. 469 (1962).

68 Thermo-Stitch, Inc. v. Chemi-Cord Processing Corp., 294 F.2d 486 (1961) (cited with approval in Dairy Queen v. Wood, 369 U.S. 469, $473 \mathrm{n.8}$ (1962)). 
The situation is somewhat different in the bankruptcy context, since in most cases the party who desires a jury trial on the counterclaim is the party who files the equitable claim rather than the party who files the counterclaim. ${ }^{67}$ Though the Beacon and Dairy Queen courts were not faced with the question of the plaintiff's right to jury trial, these cases must also be read to protect that right. There is no doubt that the two cases have given the right to jury trial a broader interpretation than it had in premerger days, since the defendant was then held to have waived his right to jury trial by filing a legal claim. ${ }^{68}$ Since the plaintiff had a right to jury trial on these issues before the merger of law and equity, ${ }^{69}$ and since the recent Supreme Court decisions do not limit that right, but extend it to the defendant, it seems reasonable to conclude that the plaintiff's right should be protected as it existed in premerger days.

The impact of these recent cases and the analysis set forth above are applicable to the plaintiffs (creditors) and defendants (trustees) in bankruptcy proceedings. The more typical ${ }^{70}$ counterclaims brought by a trustee in bankruptcy are legal in nature, and therefore the claimant in such cases is entitled to a jury trial under the seventh amendment. ${ }^{71}$ First, those claims that the trustee may institute because he has acquired the bankrupt's right ${ }^{72}$ range over the broad spectrum of legal and equitable actions, and thereby include contract and tort actions which are legal in nature. Furthermore, the trustee's right to recover voidable preferences, ${ }^{73}$ chattels or cash held by parties who received the property either in a fraudulent transfer or by executing and collecting a voidable lien ${ }^{74}$ are also legal in nature, since at common law actions of trover and money had and received were the appropriate actions to recover such property. ${ }^{75}$ The legal nature

67 See, e.g., Katchen v. Landy, 336 F.2d 535 (10th Cir. 1964), cert. granted, 380 U.S. 971 (1965).

68 See text accompanying notes 56-57 supra.

69 See text accompanying note 58 supra.

70 The bulk of the recent counterclaim cases in the circuit courts has involved counterclaims for preferences and contractual claims. See, e.g., Katchen v. Landy, 336 F.2d 535 (10th Cir. 1964), cert. granted, 380 U.S. 971 (1965) (preference); Nortex Trading Corp. v. Newfield, 311 F.2d 163 (2d Cir. 1962) (preference); Peters v. Lines, 275 F.2d 919 (9th Cir. 1960) (contract); Continental Cas. Co. v. White, 269 F.2d 213 (4th Cir. 1959) (preference); Inter-State Nat1 Bank v. Iuther, 221 F.2d 382 (10th Cir. 1955), cert. dismissed per stipulation, 350 U.S. 944 (1956) (preference); Columbia Foundry v. Lochner, 179 F.2d 630 (4th Cir. 1950) (contract).

71 See text accompanying note 51 supra.

72 Bankruptcy Act $\$ 70($ a), 52 Stat. 879 (1938), 11 U.S.C. $\$ 110(2)$ (1964).

73 Bankruptcy Act $\$ 60$ (b), 52 Stat. 870 (1938), 11 U.S.C. $\$ 96(\mathrm{~b})$ (1964).

74 Bankruptcy Act $\$ 67,52$ Stat. 875 (1938), 11 U.S.C. $\$ 107$ (1964).

75 See, e.g., Billon v. Hyde, 1 Ves. Sen. 326 (1749) (action of trover by assignees to recover property preferentially transferred); Cooper v. Chitty, 1 Burr. 19, 97 E.R. 166 (1756) (Lord Mansfield) (action of trover against sheriff who had executed writ of fieri facias against bankrupt) ; Martin v. Pewtress, 4 Burr. 2478, 98 E.R. 299 (1769) (action of trover to recover goods fraudulently transferred); Rust v. Cooper, 2 Cowp. 629, 98 E.R. 1277 (1777) (action of trover to recover value of goods fraudulently transferred) ; Smith v. Milles, 1 T.R. 475, 99 E.R. 1205 (1786) (citing Cooper v. Chitty, supra); Thompson v. Freeman, 1 T.R. 155, 99 E.R. 1026 (1786) (action of trover to recover goods of which third party took possession after confession of judgment by bankrupt); see cases cited in Schoenthal v. Irving Trust Co., 287 U.S. 92, 94 n.1 (1932). See generally Cooke, BANKRUPT LAWS 322-28 (1786); GLeNN, Fraudulent Conveyances and Preferences $\$ \$ 98,417$ (1940). 
of a trustee's suit to recover a preference has been explicitly recognized by the Supreme Court in Schoenthal v. Irving Trust Co., ${ }^{78}$ in which the Court held that the defendant in such an action has a right to jury trial under the seventh amendment.

It has already been held that a trustee has a right to jury trial on his legal counterclaim. ${ }^{77}$ Since the trustee has this right, there is no reason why the claimant should not be similarly protected, since the rationale for extending the right to the defendant in an equitable action suggests similar treatment for a claimant in bankruptcy proceedings. One of the primary reasons for protecting the defendant's right to jury trial after the merger of law and equity, is that the Federal Rules encourage joinder of causes in one action ${ }^{78}$ and compel the defendant to counterclaim in certain circumstances. ${ }^{79}$ This compulsion rationale applies equally well to the claimant in bankruptcy, since the latter can initiate proceedings to recover on his claim only by filing in the bankruptcy court. If the creditor does not file, the only other possible way he can collect his claim is to wait for the trustee to institute plenary proceedings against him. This assumes, however, that the creditor is aware of the trustee's claim and that the trustee will in fact try to recover it. Thus, for all practical purposes, the creditor is under a similar compulsion to file his claim as the defendant (or trustee) is to counterclaim in equitable proceedings. If the creditor is forced to waive his right to jury trial by filing a claim in the only tribunal which has power to hear it, this would, in effect, be putting a price on using the federal courts, which seems to raise serious due process problems. The compulsion rationale, coupled with the premerger practice of safeguarding the equitable claimant's right to jury trial on legal counterclaims and colored by the Supreme Court's present rigid position on the right to jury trial, strongly suggests the adoption of a procedure which will allow the claimant in bankruptcy to secure a jury trial on the counterclaim.

Another argument for ending the "consent by filing" doctrine may be made on the basis of Rules 38 and 39 of the Federal Rules of Civil Procedure. $^{80}$ Rule 38(b) states that a demand for jury trial on an issue may be asserted within ten days after the last pleading to such issue. Rule 38(d) provides that a failure to serve a demand constitutes a waiver of jury trial. The rule further states that "a demand for trial by jury . . . may not be withdrawn without the consent of the parties." Moreover, Rule 39(a) provides that:

76287 U.S. 92 (1932).

77 See Black v. Boyd, 248 F.2d 166 (6th Cir. 1957).

78 See FED. R. CIV. P. 18(a) (permitting joinder of all claims whether legal or equitable).

T9 FED. R. CIv. P. 13(a).

${ }^{80} \mathrm{FED} . \mathrm{R}$. Crv. P. 38(a) provides: "The right of trial by jury as declared by the Seventh Amendment to the Constitution or as given by a statute of the United States shall be preserved to the parties inviolate." 
when trial by jury has been demanded as provided in Rule 38, the action shall be designated upon the docket as a jury action. The trial of all issues so demanded shall be by jury, unless (1) the parties or their attorneys of record, by written stipulation filed with the court or by an oral stipulation made in open court and entered in the record, consent to trial by the court sitting without a jury ....

These rules are so explicit that it seems likely that Congress intended to limit waiver of jury trial to cases where there was either a failure to demand jury trial or a written or oral consent to trial without a jury. Thus, implied consent to waiver would not be an available doctrine. The fact that Rule 39(a) (2) permits a court to find that a right to jury trial does not exist under the Constitution or statutes of the United States 81 does not disturb the validity of the preceding analysis. In the first place, the circuit courts have not contended that the creditor has no right to jury trial on legal counterclaims, they merely argue that he waives this right by filing his claim. Furthermore, as demonstrated above, there seems to be no doubt that an equitable claimant has a right to jury trial on legal counterclaims.

In light of the jury trial issue, the circuit courts' collateral estoppel rationale for allowing summary jurisdiction of related legal counterclaims seems untenable. As mentioned above, the circuit courts have emphasized the trustee's right to have a summary adjudication of the issues upon which his counterclaim is based if these issues are raised in answer to the creditor's claim. From this, the courts have concluded that a plenary proceeding would only be a wasteful expenditure of time, since the issues raised in the summary proceeding would be collateral estoppel in the plenary proceedings. ${ }^{82}$ Even if the objections noted above to this approach 83 are not accepted, the Beacon Theatres-Dairy Queen rule still outweighs the collateral estoppel policy. In the Beacon Theatres case, the facts on which Beacon based its counterclaim-that Fox West Coast Theatres and Beacon were competitors and that the clearance period between Beacon and Fox was reasonable-would also have been sufficient to constitute a defense to Fox's equitable claim. However, the entire impact of Beacon Theatres was its support for the general proposition that lower courts should not disregard the right to jury trial on the strength of technical distinctions. The Court in that case carefully emphasized that

81 FED. R. CIV. P. 39(a) (2) provides:

The trial of all issues so demanded shall be by jury, unless . . . (2) the court upon motion or of its own initiative finds that a right of trial by jury of some or all of those issues does not exist under the Constitution or statutes of the United States.

82 See, e.g., In re Solar Mfg. Corp., 200 F.2d 327, 330 (3d Cir. 1952), cert. denied sub nom., Marine Midland Trust Co. v. McGirl, 345 U.S. 940 (1953).

83 See text accompanying notes 27-32 supra. 
"maintenance of the jury as a fact-finding body is of such importance and occupies so firm a place in our history and jurisprudence that any seeming curtailment of the right to a jury trial should be scrutinized with the utmost care." 84 This strong defense of the right to jury trial ${ }^{85}$ establishes a constitutionally based policy strong enough to subordinate the competing and somewhat disfavored policy of collateral estoppel.86 Moreover, since the trustee has a duty to recover adversely held claims for the bankrupt estate, ${ }^{87}$ the collateral estoppel policy should carry no weight in bankruptcy proceedings. Allowing the trustee to plead as a defense facts sufficient to state a cause of action would merely permit him to prevent a claimant from acquiring a jury trial on this cause of action.

\section{Conclusion}

The validity of the circuit courts' position on waiver of jury trial is presently before the Supreme Court in Katchen $v$. Landy, ${ }^{88}$ certiorari having been granted. If the Court continues its strong protection of the right to jury trial in this case, a different procedure will have to be chosen for future counterclaim cases in the bankruptcy court. One possible alternative is adoption of the procedure employed by the Fifth Circuit, ${ }^{89}$ which does not follow the "consent by filing" doctrine. Under this approach, the creditor's claim is left pending before the referee, and the trustee is ordered to prosecute the plenary suit to establish his cause of action on the counterclaim. It should be noted that in the Fifth Circuit case establishing this procedure the counterclaim was based upon the theory that the creditor had received a voidable preference.

The Fifth Circuit procedure compels the trustee to go through all the formalities of instituting a suit. Process must be served, a complaint must be filed, and other technicalities must be satisfied. Moreover, under section 23 , the trustee may also be forced to bring the suit in a state court, if there is no diversity of citizenship. ${ }^{90}$ Thus, the trustee may be able to recover the preference from the creditor only after successfully prosecuting a state court determination of the issue in a plenary proceeding with a jury trial..$^{91}$ Completion of this lengthy process would be required before

84 Beacon Theatres, Inc. v. Westover, 359 U.S. 500, 501 (1959) (quoting Dimick v. Schiedt, 293 U.S. 474, 486 (1935)).

85 See also Byrd v. Blue Ridge Rural Elec. Corp., Inc., 356 U.S. 525 (1958) (federal policy favoring jury decisions of disputed fact questions outweighs policy of Erie v. Tompkins).

86 See generally Cleary, Res Judicata Reexamined, 57 Y ALE L.J. 339 (1948).

87 Bankruptcy Act $\S 47,52$ Stat. 860 (1938), as amended, 11 U.S.C. $\$ 75$ (1964).

88336 F.2d 535 (10th Cir. 1964), cert. granted, 380 U.S. 971 (1965).

89 See B. F. Avery \& Sons v. Davis, 192 F.2d 255 (5th Cir. 1951), cert. denied, 342 U.S. 945 (1952).

90 Bankruptcy Act $\S 23,52$ Stat. 854 (1938), 11 U.S.C. $\$ 46$ (1964).

01 See ibid.; Taubel-Scott-Kitzmiller Co. v. Fox, 264 U.S. 426, 433-34 (1924); O'Dell v. United States, 326 F.2d 451, 455 (10th Cir. 1964); In re Prima, 98 F.2d 952, 957 (7th Cir.), cert. denied, 305 U.S. 658 (1938). 
the referee could finally adjudicate the creditor's claim, which would be held pending during the state court trial. The expenditure of time required by this procedure explains why most courts have been willing to imply consent to summary jurisdiction when a creditor files his claim. If the trustee's counterclaim were not based upon a preference or other section $57(\mathrm{~g})$ type issue, ${ }^{22}$ there would seem to be no reason for holding the creditor's claim pending before the referee. His claim could be adjudicated and the trustee could simultaneously prosecute his action in a plenary proceeding. Even this procedure, however, would be cumbersome and time consuming, and most of the issues litigated in the summary proceeding would have to be relitigated in the plenary proceeding.

A more expeditious alternative has been suggested by the Second Circuit in Kleid v. Ruthbell Coal Co.93 The court permitted the creditor in that case to withdraw his claim when the trustee alleged in defense that the creditor had received a voidable preference. The creditor's withdrawal was conditioned, however, on his consenting: (1) to the district court having subject matter jurisdiction, (2) to accept summons, and (3) to the early setting of a trial date. This procedure retains the good points of the present system employed by the circuit courts, while maintaining the claimant's right to a jury trial on the trustee's counterclaim. By conditioning the procedure on the claimant's consent to federal jurisdiction, no speed of administration is lost, since federal courts generally have docket delays similar to those in state courts. ${ }^{94}$ Moreover, both the creditor's claim and the trustee's counterclaim will be litigated in one proceeding. This procedure is thus a more reasonable method of implementing the creditor's right to jury trial than that of the Fifth Circuit.

The Kleid solution, however, is inadequate in two situations. It cannot be employed if the creditor does not wish to withdraw his claim and is also useless where the trustee counterclaims, rather than merely defending on the preference theory. The problem in this latter situation is that Rule 41 (a) (2) of the Federal Rules of Civil Procedure does not allow the withdrawal of a claim after a counterclaim has been made unless the counterclaim alone can be adjudicated in the court in which it was made. The court circumvented this problem in Kleid by classifying the trustee's objection to the claim on the voidable preference theory as an affirmative defense rather than a counterclaim.

There is, however, a third alternative which would avoid these problems and would be satisfactory in most cases: if the creditor makes a

92 Bankruptcy Act $\S 57(\mathrm{~g}), 52$ Stat. 866 (1938), 11 U.S.C. $\S 93(\mathrm{~g})$ (1964) provides:

The claims of creditors who have received or acquired preferences, liens, conveyances, transfers, assignments or encumbrances, void or voidable under this Act, shall not be allowed unless such creditors shall surrender such preferences, liens, conveyances, transfers, assignments, or encumbrances.

93131 F.2d 372 (2d Cir. 1942).

94 See generally 328 The Annals of the American Academy of Political and Soctal ScIENCE 7-28 (1960). 
demand for jury trial and for plenary proceedings after the trustee counterclaims, the court would set the entire action for adjudication in a federal court with a jury trial. The possible problem with this alternative is that if there is no diversity of citizenship, the creditor may refuse consent to have the counterclaim adjudicated in a federal court and insist that the cause of action be instituted in a state court. ${ }^{95}$

In sum, all three procedures discussed above have deficiencies, and only the cumbersome procedure of the Fifth Circuit falls clearly within the statute. Thus a complete solution to all the problems must lie in a congressional amendment of the Bankruptcy Act giving the federal courts jurisdiction even over counterclaims which concern property not in the actual or constructive possession of the trustee. Such a change would require a creditor faced with a counterclaim to adjudicate both it and his original claim in the federal court, while still receiving a jury trial if he so demanded.

95 This Comment has not discussed whether the bankruptcy court could imply consent to federal jurisdiction from the creditor's filing of his claim, it has only assumed that even if consent to federal jurisdiction could be implied, consent to summary proceedings on the counterclaim or waiver of jury trial could not be. If a court did grant the claimant plenary proceedings and a jury trial, then implying consent to federal jurisdiction would not be unreasonable. However, since the Bankruptcy Act only gives the bankruptcy court jurisdiction when it has actual or constructive possession of the property sought to be recovered, it would seem inconsistent to imply such consent. The quasi in rem analogy also seems to support the position that consent to federal jurisdiction cannot be implied. See note 42 supra. 